\title{
Development of sun protection behaviors in preschoolers: A systematic review
}

\author{
Anaokulu öğrencilerinde güneșten korunma davranıșlarının geliștirilmesi:
} Sistematik derleme

\section{Adem Sümen, ๑ Selma Öncel*}

Manavgat State Hospital, Antalya, Turkey

*Akdeniz University Faculty of Nursing, Department of Public Health Nursing, Antalya, Turkey

\begin{abstract}
Background and Design: Intense studies have been conducted in the world for the purpose of protecting children from the sun and raising awareness of sun protection at early age. Thus, the aim of the study is to evaluate sun protection interventions for preschoolers. Materials and Methods: This study was conducted under the guidance of PRISMA-P declaration. The articles were conducted in the study using the databases of Cochrane, PubMed, ScienceDirect, CINAHL, Clinical Key/Elseiver, Ovid, MEDLINE and the terms of "Skin Neoplasms", "Sun Protection Factor", "Child, Preschool", "Randomized Controlled Trial" MeSH without any year restriction in March 2016. Randomized controlled studies applying sun protection steps at preschool education institutions and being conducted in English were included in the study. Results: In the systematic review, five research articles selected according to study criteria were examined and it was observed that the interventions were aimed at students, parents, teachers and school administrators. All of the studies were conducted between 1995-2007, four in the United States of America and one in Germany. Programs conducted in the articles were formed based on Piaget's cognitive development theory, Health Belief Model, and Social Learning Theory. In the programs, behaviors of children were observed at kindergartens and information and attitudes of kindergarten administrators, sun protection applications, facilities/obstacles/policies of school, sun protection behaviors of children from the perspective of parents, sun protection behaviors of teachers and parents for children and psychosocial variables were evaluated. Conclusion: The intervention was observed to be efficient in four out of these five researches included in the study. Due to the importance of sun exposure in childhood, the early development of sun protection awareness is extremely important. It is thought that this systematic review will prepare a basis for future studies by drawing attention to effective models in sun protection education for children.
\end{abstract}

Keywords: Skin neoplasms, sun protection factor, child, preschool, review

Öz

Amaç: Dünyada çocukların güneşten korunmaları ve güneşten korunma bilincinin erken yaşta oluşturulması için yoğun çalışmalar yürütülmektedir. Güneşli ülkede yaşayan ve yaşayacak olan genç nüfusun sağlıklı bireyler olarak yetişmeleri, erken dönemde edindikleri doğru bilgi ve alışkanlıklara bağlıdır. Bu nedenle çalışmada anaokulu öğrencilerine yönelik yapılan güneşten korunma müdahalelerini değerlendirmek amaçlanmışır. Gereç ve Yöntem: Bu çalışma, PRISMA-P (Preferred Reporting Items for Systematic Review and Meta-Analysis Protocols) bildirgesi rehber alınarak yapılmışıı. Çalışma kapsamına alınacak makaleler; herhangi bir yıl sınırlaması yapmaksızın, Cochrane, PubMed, ScienceDirect, CINAHL, Clinical Key/Elseiver, Ovid, MEDLINE veri tabanlarr; "Skin Neoplasms", "Sun Protection Factor", "Child, Preschool", "Randomized Controlled Trial" MeSH terimleri kullanılarak, Mart 2016 tarihinde yapılmıştır. Okul öncesi eğitim kurumlarında, güneşten korunma adımlarının çocukların kendilerine, ailelerine ve öğretmenlerine uygulandığı, yayın dili İngilizce olan randomize kontrollü araştırmalar çalışma kapsamına alınmıştır. Bulgular: Sistematik derlemede araştırma kriterlerine göre seçilmiş beş araştırma makalesi incelenmiş ve girişimlerin öğrencilere, ebeveynlerine, öğretmenlerine, okul yöneticilerine yönelik uygulandığı görülmüştür. Araştırmaların tamamı 1995-2007 yıllarında, dördü Amerika Birleşik Devletleri'nde ve bir tanesi Almanya'da yapılmıştı. Çalışmalarda yürütülen programlar Piaget'in bilişsel gelişim teorisi, Sağlık Inanç Modeli ve Sosyal Öğrenme Teorisi'ne temellendirilerek oluşturulmuştur. Uygulanan programlarda anaokulunda çocukların davranışları

Address for Correspondence/Yazışma Adresi: Adem Sümen Nurse, Manavgat State Hospital, Antalya, Turkey Phone.: +90 5374695700 E-mail: adem_sumen@hotmail.com Received/Geliş Tarihi: 03.07.2017 Accepted/Kabul Tarihi: 22.01.2018 ORCID ID: orcid.org/ 0000-0002-8876-400X

CCopyright 2018 by Turkish Society of Dermatology and Venereology

Turkderm-Turkish Archives of Dermatology and Venereology published by Galenos Yayınevi. 
gözlemlenmiş, anaokulu yöneticilerinin bilgi, tutumları, güneşten korunma uygulamaları, okulun imkanları, engelleri, politikaları, ebeveynlerin gözünden çocukların güneşten korunma davranışları, öğretmenlerin ve ebeveynlerin çocuklar için güneşten korunma davranışları ve psikososyal değişkenleri değerlendirilmiştir. Sonuç: Araştırma kapsamına alınan bu beş araştırmanın dördünde yapılan girişimin etkin olduğu belirlenmiştir. Konu ile ilgili çalışmaların henüz az olduğu ve daha fazla randomize kontrollü çalışmalara gereksinim olduğu ortaya çıkmışır. Çocukluk çağındaki güneş maruziyetinin önemi nedeniyle güneşten korunma bilincinin erken dönemde oluşturulması son derece önemlidir. Bu sistematik derlemenin çocuklara yönelik güneşten korunma eğitiminde etkili modellere dikkati çekerek ileriki çalışmalar için temel hazırlayacağı düşünülmektedir.

Anahtar Kelimeler: Deri neoplazmları, güneş koruyucu faktör, çocuk, okul öncesi, gözden geçirme

\section{Introduction}

There has been a growing concern over the increased incidence of skin cancers across the world, including Turkey. It has been reported that over a lifetime, one in 39 men and one in 58 women will develop skin cancer ${ }^{1}$. The most important factor in the etiology of skin cancer is ultraviolet (UV) rays ${ }^{2,3}$. Thinning of the ozone layer has intensified exposure to UV rays, which creates an important risk for skin cancer ${ }^{4,5}$. As one of the most common health problems in the world, skin cancer has a considerable disease burden, as it has a wide multidimensional influence, one that impacts patients, families, and community, in terms of psychological, social, and financial aspects ${ }^{6}$.

To decrease the burden of skin cancers on public health, it is of primary importance to reduce the amount of exposure to UV radiation through sunlight by developing positive behaviors for sun protection?. The adverse effects of UV rays on human health have been exacerbated by a number of factors, including the tanning trend in society, which is related to the psychological effect of looking good, familial behavior models (e.g., belief that tanned skin is healthy and the spread of this belief), and the continued popularity of vacationing "under the $\operatorname{sun}^{\prime \prime 8,9}$. Given the role of high sun exposure during childhood in the development of skin cancer, it is imperative that parents take active measures to protect their children against the sun in this period, and that educational institutions provide instructional programs about this issue ${ }^{10,11}$. Parental behaviors play a key role in protecting children against solar UV radiation, particularly in terms of parents being a positive role model for their children by the behaviors and attitudes they exhibit ${ }^{12,13}$. Numerous positive and negative preventive health behaviors are initially shaped in the family, followed by the school and social environment. Schools share a bulk of the responsibility for creating an atmosphere wherein health promotion practices are supported ${ }^{14,15}$

Different studies have been conducted throughout the world that have focused on protecting children from the sun and creating awareness on sun protection at an early age. The success of achieving these goals largely depends on providing correct information and instilling proper habits in the early period of youth to raise healthy, responsible individuals who currently live or may live in sunny countries. Therefore, the aim of this systematic review was to evaluate the sun protection interventions carried out for preschoolers. This systematic review sought to answer the following questions:

-Which model/theory-based interventions were applied to develop sun protection behaviors in preschoolers?

-Were these interventions effective?

\section{Materials and Methods}

The present review was carried out in accordance with the Preferred Reporting Items for Systematic Review and Meta-Analysis Protocols
(PRISMA-P) statement used to guide authors in improving the presentation of systematic reviews and meta-analysis studies ${ }^{16}$.

\section{Research strategy}

A search for the articles to be reviewed in the study was performed in March of 2017 using the databases of Cochrane, PubMed, ScienceDirect, CINAHL, Clinical Key/Elsevier, Ovid, and MEDLINE, accessed through $\mathrm{MeSH}$, in which the key words, "Skin Neoplasms", "Sun Protection Factor", "Child, Preschool", and "Randomized Controlled Trial (RCT)" were used without any year limitation. The snowball sampling technique was used for conducting the literature review.

\section{Inclusion criteria}

In this systematic review, the PICOS method (P: Population-Participants, I: Interventions, C: Comparisons-Comparison groups, O: Outcomes, S: Study designs) was used for the inclusion criteria ${ }^{17}$.

$P$ : Sun exposure during childhood is a key contributor to the development of skin cancer ${ }^{18-21}$. Therefore, studies conducted with children in preschool education institutions constituted the target group of this study.

I: Education initiatives on skin cancer and sun protection, as well as experimental studies based on one or all the sun protection behaviors, such as using sunscreen, staying in shaded areas, avoiding being outside between 10.00 and 16.00, and wearing wide-brimmed hats and sunglasses, as well as long-sleeved attire, were included ${ }^{22-26}$

C: It was aimed to compare three different variables in studies conducted on skin cancer and sun protection during childhood, namely, a comparison of the effects of interventions made for children, their families, and their teachers.

O: Results related to interventions, preventing risk factors associated with skin cancer, policies of school, expectancies, and impediments were evaluated.

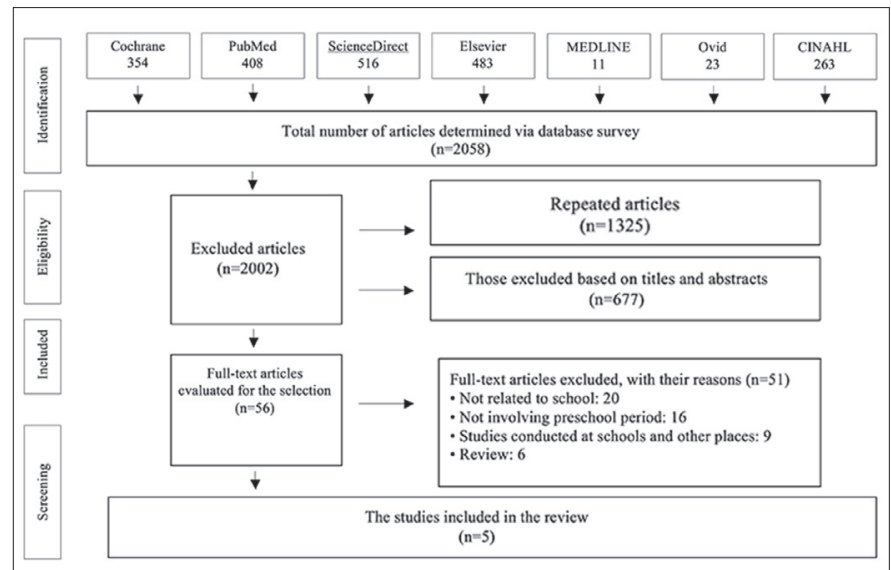

Figure 1. Flow chart indicating selection process of the studies (Preferred Reporting Items for Systematic Review and Meta-Analysis Protocols flow chart) 
S: RCT that were published in English and had high levels of evidence on the subject were chosen.

\section{Selection of the studies}

The whole process for determining the examined studies can be seen in Figure 1, where it is presented in the form of the PRISMA-P flow chart, with numerical data. The first stage of this process involved a review of the databases by searching terms, titles abstracts and key words through $\mathrm{MeSH}$. The first researcher investigated titles and abstracts of the articles to access possible studies, while the second researcher read and evaluated the titles and abstracts of the articles accessed, identifying and deleting any repeated studies. Once the full texts of the remaining studies were obtained, they were recorded in a data summary form and prepared according to the inclusion criteria by two independent researchers, and the suitable studies were then selected. The snowball sampling method was used in these stages. In the evaluation of the texts, the two researchers were largely in agreement on which ones should be selected for the study review, and in the few cases of disagreement, the two reached a decision by consensus.

\section{Evaluating quality of evidence}

In systematic reviews and meta-analysis studies, effective use of study results that have been synthesized correctly for clinical care is made possible through the accurate evaluation of research quality ${ }^{27}$. The methodological quality of a study is determined by evaluating the quality of research with standardized tools, from which any incidences of bias, in terms of study design, stages of application, and statistical analysis methods, are identified ${ }^{28}$.

The Joanna Briggs Institute (JBI) has developed tools of critical evaluation Meta-Analysis of Statistics Assessment and Review Instrument (MAStARI) to assess the methodological quality of qualitative and quantitative studies. The JBI-MAStARI-recommended checklist (10 items) for experimental and quasi-experimental studies is used to assess the methodological quality of research articles to be included within the scope of meta-analysis and systematic reviews. Although the evaluation criteria vary depending on the characteristics required by different types of study design, the items on the checklists of JBI-MAStARI generally aim to evaluate four types of bias, namely, "selection bias", "performance bias", "detection bias", and "attrition bias", in studies $^{17}$. This tool was adapted to the Turkish language by Nahcivan and Seçginlii28 in 2015, and it was found that the content validity index was 0.90 and the Cronbach's alpha coefficient was 0.68 . For each item on the checklists of the JBI-MAStARI, "Yes" is scored 1 point; whereas, "No", "Not stated", and "Inappropriate" are scored 0 points. The assessment score ranges from 0 to 10, with high total scores signifying high methodological quality of the study.

\section{Data analysis}

All the studies included were synthesized using the criteria of the JBI-Qualitative Assessment and Review Instrument (JBI-QARI) data assessment too ${ }^{17}$. These criteria served to assist in how the data would be managed, collected, and combined and in minimizing error risk. The information that had been sorted out independently by the researchers and recorded on the form was revised again based on a new form that had been revised and prepared in accordance with JBI-QARI data assessment tool. The number of participants on which the interventions were applied and the study quality score were also included as part of this assessment.

Among the studies included in the study review, there were differences identified in the methods and interventions applied for education on sun protection, as well as differences between measurement tools. Based on this heterogeneity of methods and interventions, a metaanalysis was unable to be conducted for the studies included, and therefore, only the results are presented.

\section{Ethical considerations}

The investigators were under no risk of financial/emotional damage during the conduct of the systematic review. The articles analyzed are shown in the references.

\section{Results}

This systematic review evaluated five research articles chosen according to the study criteria (Table 1$)^{29-33}$. The results obtained from the studies were grouped under the headings of "Research groups and characteristics", "Characteristics of program applied", "Evaluation of program applied", "Results obtained", and "Methodological quality of the studies", all of which are described in greater detail below.

\section{Research groups and characteristics}

All the studies were RCTs conducted between 1995 and 2007, with four being carried out in the United States of America ${ }^{9,30,32,33}$ and one in Germany ${ }^{31}$. Regarding the samples of the studies included in the research, two consisted of children ${ }^{29,31}$ one of parents ${ }^{32}$, and one of preschool personnel ${ }^{33}$, parents, and school principals ${ }^{30}$. The participants constituting the samples of these studies were either divided into three groups, that is, two intervention groups and one control group ${ }^{31}$, or into two groups $29,30,32,33$. A study by Bauer et al. ${ }^{31}$ (2005) was found to have the largest sample size (training group: 369 persons, training and sunscreen group: 465 persons, control: 398 persons), while that of Loescher et al. ${ }^{29}$, (1995) was found to have the smallest sample (total: 142 students; intervention group: 66 and control group: 76).

\section{Characteristics of the program applied}

The studies included in the review were conducted based on Piaget's theory of cognitive development ${ }^{29}$, the Health Belief Model ${ }^{30}$, and the Social Cognitive Theory ${ }^{32,33}$. The slogans of "Be Sun Safe Curiculum"29, "Block the Sun, Not the Fun"30, and "Sun Protection is Fun! (SPF)"32,33 were used in the studies. In a study by Loescher et al. ${ }^{29}$, (1995), as part of the semester-long program administered, lessons on sun protection were added to the curriculum, subjects were explained, and various activities (puppet show, games related to sun protection, artistic activities, songs, story books) were organized. Crane et al. ${ }^{30}$, (1999), in their study, conducted training sessions for school employees, distributed materials to families (brochures, magnets) and sunscreen to children, introduced the families to different applications that they could practice and educated them on the subject in the spring semester of the academic year to ensure that the children, through the guidance of their families, would understand how to be protected from the sun. The information that the school superintendents had about the issue was also obtained and school policies were reviewed. Differently from 
the others, Bauer et al. ${ }^{31}$, (2005), in their study, formed two intervention groups, one of whom (the education intervention group) they sent informational letters and brochures to about sun protection and the use of sunscreen three times a year (Easter, Pentecost, and summer holidays) for three years. The training and sunscreen intervention group, on the other hand, was given training material and free sunscreen

Table 1. Characteristics of the studies included in the review

\begin{tabular}{|c|c|c|c|c|c|c|c|}
\hline $\begin{array}{l}\text { Author, } \\
\text { year, and } \\
\text { country }\end{array}$ & $\begin{array}{l}\text { Characteristics } \\
\text { of the study }\end{array}$ & $\begin{array}{l}\text { Characteristics of } \\
\text { the participants }\end{array}$ & Interventions & Application & Evaluation & Results & $\begin{array}{l}\text { Quality } \\
\text { score }\end{array}$ \\
\hline $\begin{array}{l}\text { Loescher et } \\
\text { al. }^{29}(1995) \\
\text { USA }\end{array}$ & $\begin{array}{l}\text { Method: RCT } \\
\text { Theory: } \\
\text { Piaget's theory } \\
\text { of cognitive } \\
\text { development } \\
\text { Slogan: Be Sun } \\
\text { Safe Curriculum }\end{array}$ & $\begin{array}{l}\text { Age: } 4-5 \text { years of age } \\
\text { Sample: One class } \\
\text { from each of the four } \\
\text { kindergartens from } \\
\text { each of the three } \\
\text { different regions } \\
\text { Intervention: } 66 \\
\text { Control: } 76\end{array}$ & $\begin{array}{l}\text { Inclusion of the } \\
\text { related chapters } \\
\text { into curriculum } \\
\text { For teachers: } \\
\text { Materials related } \\
\text { to tanning, } \\
\text { ultraviolet rays, } \\
\text { skin, skin cancer } \\
\text { and risk factors } \\
\text { Content of } \\
\text { chapter: Aim, } \\
\text { goals, usable } \\
\text { materials, } \\
\text { materials for class } \\
\text { and home, key } \\
\text { words, learning } \\
\text { resources; each } \\
\text { lesson lasts } 40-45 \\
\text { minutes } \\
\text { Interactive } \\
\text { activities: Puppet } \\
\text { show, games } \\
\text { related to sun } \\
\text { protection, artistic } \\
\text { activities, songs, } \\
\text { and story books }\end{array}$ & $\begin{array}{l}\text { Measurements: Before and after } \\
\text { intervention } \\
\text { Pretest: The first measurement before } \\
\text { application of the curriculum } \\
\text { Application: } 1 \text { term } \\
\text { Posttest 1: In the } 2^{\text {nd }} \text { week following } \\
\text { the curriculum } \\
\text { Posttest 2: In the } 7^{\text {th }} \text { week following the } \\
\text { curriculum }\end{array}$ & $\begin{array}{l}\text { Photographs to } \\
\text { measure three cognitive } \\
\text { levels (knowledge, } \\
\text { understanding, practice) } \\
\text { of children for sun } \\
\text { protection }\end{array}$ & $\begin{array}{l}\text { The curriculum } \\
\text { was found to be } \\
\text { an effective tool } \\
\text { for giving pre- } \\
\text { school children } \\
\text { knowledge and } \\
\text { an understanding } \\
\text { of sun protection; } \\
\text { even though it } \\
\text { had an effect on } \\
\text { the application, } \\
\text { this effect was } \\
\text { not statistically } \\
\text { significant. The } \\
\text { curriculum was well } \\
\text { received by the } \\
\text { children, parents, } \\
\text { and kindergartens }\end{array}$ & 8 \\
\hline $\begin{array}{l}\text { Crane et al. }{ }^{30} \\
\text { (1999) USA }\end{array}$ & $\begin{array}{l}\text { Method: RCT } \\
\text { Theory/model: } \\
\text { Health Belief } \\
\text { Model } \\
\text { Slogan: Block the } \\
\text { Sun, Not the Fun }\end{array}$ & $\begin{array}{l}\text { Age: Parents; } \\
\text { Between } 30-39 \text { years } \\
\text { Sample: Managers } \\
\text { and staff members } \\
\text { of } 27 \text { Public licensed } \\
\text { kindergartens and } \\
\text { nurseries, and } \\
\text { parents } \\
\text { Intervention: } 13 \\
\text { schools } \\
\text { Control: } 14 \text { schools } \\
\text { Total number of } \\
\text { participants; parents } \\
\text { ( } n=201), \text { managers } \\
\text { ( } n=27)\end{array}$ & $\begin{array}{l}\text { Major focus of the } \\
\text { intervention; } \\
\text { - Improving sun } \\
\text { protection of } \\
\text { children while they } \\
\text { were at schools, } \\
\text { - Improving } \\
\text { parents' ability } \\
\text { to protect their } \\
\text { children from the } \\
\text { sun and training } \\
\text { them about sun } \\
\text { protection } \\
\text { For staff of } \\
\text { kindergartens } \\
\text { and nurseries: } \\
\text { Two workshops } \\
\text { that lasted } \\
\text { for } 3 \text { hours } \\
\text { (Presentation by } \\
\text { a dermatologist, } \\
\text { Q/A session, } \\
\text { session for } \\
\text { improving } \\
\text { personal } \\
\text { preventive } \\
\text { measures for skin } \\
\text { cancer, children } \\
\text { participation in } \\
\text { activities) } \\
\text { For Families: } \\
\text { Brochures for } \\
\text { sun protection, } \\
\text { learning activities } \\
\text { to be completed } \\
\text { with children, } \\
\text { sunscreen, and } \\
\text { "Block the Sun, } \\
\text { Not the Fun" } \\
\text { magnets }\end{array}$ & $\begin{array}{l}\text { Measurements: Before and after the } \\
\text { intervention } \\
\text { The first measurement: Review of } \\
\text { questionnaire, observations, and written } \\
\text { policies for managers in the summer } \\
\text { of } 1993 \\
\text { Application: In the spring of } 1994 \\
\text { The second measurement: Review of } \\
\text { questionnaire, observations, and written } \\
\text { policies for managers in the summer of } \\
\text { 1994, questionnaire for parents at the } \\
\text { end of the summer of } 1994\end{array}$ & $\begin{array}{l}\text { Questionnaires } \\
\text { for managers: Sun } \\
\text { protection applications } \\
\text { of the center, its } \\
\text { impediments, } \\
\text { characteristics of } \\
\text { children, and the } \\
\text { financial turnover. Their } \\
\text { knowledge/attitudes } \\
\text { on and practices for } \\
\text { protecting themselves } \\
\text { from the sun } \\
\text { Observations: } \\
\text { 30-minute observation } \\
\text { with 5-minute intervals } \\
\text { for six children } \\
\text { randomly chosen from } \\
\text { the playground during } \\
\text { outdoor activities } \\
\text { Review of policies: } \\
\text { Demands of school } \\
\text { from parents for } \\
\text { sunscreen, hat, } \\
\text { protective clothing, and } \\
\text { demands of parents for } \\
\text { the use of sunscreen } \\
\text { Questionnaire for } \\
\text { parents: Sun protection } \\
\text { applications of family in } \\
\text { kindergarten or daytime } \\
\text { nursery establishment; } \\
\text { sun protection } \\
\text { applications used by } \\
\text { family, their knowledge } \\
\text { and attitudes about } \\
\text { skin cancer and } \\
\text { sun protection } \\
\text { and demographic } \\
\text { characteristics }\end{array}$ & $\begin{array}{l}\text { Although the } \\
\text { interventions did not } \\
\text { appear to change } \\
\text { the sun protection } \\
\text { attitudes and } \\
\text { behaviors of parents } \\
\text { or the behaviors } \\
\text { of centers in terms } \\
\text { of using proper } \\
\text { clothing and staying } \\
\text { in the shade, the } \\
\text { results revealed } \\
\text { significant changes } \\
\text { in sun protection } \\
\text { knowledge/attitudes } \\
\text { of managers and the } \\
\text { use of sunscreen by } \\
\text { centers }\end{array}$ & 7 \\
\hline
\end{tabular}


Table 1 continue

\begin{tabular}{|c|c|c|c|c|c|c|c|}
\hline $\begin{array}{l}\text { Bauer et al. }{ }^{31} \\
(2005) \\
\text { Germany }\end{array}$ & $\begin{array}{l}\text { Method: RCT } \\
\text { Theory: None } \\
\text { Slogan: None }\end{array}$ & \begin{tabular}{|l|} 
Age: $2-7$ years \\
Sample: students \\
with Fitzpatrick skin \\
type 1-4 who were \\
selected from 78 \\
public kindergartens \\
from two different \\
regions \\
Training group: 369 \\
Training \& sunscreen \\
group: 465 \\
Control: 398
\end{tabular} & \begin{tabular}{|l|} 
Two intervention \\
groups \\
For training \\
group: \\
Informational \\
letters about sun \\
protection and the \\
use of sunscreen \\
three times a \\
year (Easter, \\
Pentecost, and \\
summer holidays), \\
brochures on \\
prevention of \\
melanoma \\
For Training \\
\& sunscreen \\
group: All the \\
materials received \\
by training group, \\
in addition to free \\
sunscreen for use \\
from spring to fall \\
\end{tabular} & $\begin{array}{l}\text { Measurements: Before and after the } \\
\text { intervention } \\
\text { Pretest: The first measurement in } \\
\text { Stuttgart in summer of } 1998 \text { and in } \\
\text { Bochum in fall of } 1998 \\
\text { Application: Average } 3 \text { years } \\
\text { Posttest: In Stuttgart in summer of } \\
2001 \text { and in Bochum in fall of } 2001\end{array}$ & $\begin{array}{l}\text { Basic characteristics } \\
\text { of the children, } \\
\text { characteristics of } \\
\text { the parents and the } \\
\text { families, children's } \\
\text { 3-year history of } \\
\text { sun exposure, } \\
\text { children's history of } \\
\text { sun protection, the } \\
\text { number of holidays } \\
\text { and the names of } \\
\text { visited countries, home } \\
\text { activities (outdoor } \\
\text { swimming, playing } \\
\text { outside, walking, } \\
\text { cycling, etc.) }\end{array}$ & $\begin{array}{l}\text { Training interventions } \\
\text { and free sunscreen } \\
\text { intervention were } \\
\text { shown not to have } \\
\text { any effect on children } \\
\text { for sun protection }\end{array}$ & 8 \\
\hline $\begin{array}{l}\text { Gritz et al. }{ }^{32} \\
\text { (2005) } \\
\text { USA }\end{array}$ & $\begin{array}{l}\text { Method: RCT } \\
\text { Theory: Social } \\
\text { cognitive theory } \\
\text { Slogan: Sun } \\
\text { Protection is Fun! }\end{array}$ & $\begin{array}{l}\text { Age: } \\
\text { Parents; aged } \\
\text { between 32-32.6 } \\
\text { years } \\
\text { Sample: Parents } \\
\text { of children from } 16 \\
\text { public and } 4 \text { private } \\
\text { kindergartens } \\
\text { Intervention: } 10 \\
\text { schools } \\
\text { Comparison: } 10 \\
\text { schools } \\
\text { Beginning ( } n=384) \text {, } \\
\text { after } 12 \text { months } \\
(n=640), \\
\text { after } 24 \text { months } \\
(n=694)\end{array}$ & $\begin{array}{l}\text { Two groups, } \\
\text { a comparison } \\
\text { group and an } \\
\text { intervention group } \\
\text { For comparison } \\
\text { group: Standard } \\
\text { public trainings } \\
\text { and brochure for } \\
\text { prevention of skin } \\
\text { cancer } \\
\text { For intervention } \\
\text { group: Sun } \\
\text { protection } \\
\text { video, bulletin, } \\
\text { handbook, skin } \\
\text { cancer guide }\end{array}$ & $\begin{array}{l}\text { Measurements: Before the } \\
\text { intervention, in the } 12^{\text {th }} \text { month and } 24^{\text {th }} \\
\text { month } \\
\text { Pretest: At the end of summer of } 1996 \\
\text { First application: Video, bulletin, } \\
\text { handbook for sun protection from June- } \\
\text { July } 1997 \\
\text { Posttest 1: At the end of } 1997 \text { summer } \\
\text { in } 12^{\text {th }} \text { month } \\
\text { - Copies of previously delivered } \\
\text { materials (Video, bulletin, handbook } \\
\text { for sun protection) were delivered to } \\
\text { parents, who were new and wanted to } \\
\text { participate, in October } 1997 \\
\text { Second application: Delivery of the } \\
\text { second bulletins in December } 1997 \\
\text { Third application: Video, the first two } \\
\text { bulletins, handbook for sun protection in } \\
\text { March 1998 } \\
\text { Fourth application: Skin cancer guide } \\
\text { in April } 1998 \\
\text { Fifth application: The third bulletin and } \\
\text { video in June } 1998 \\
\text { Sixth application: Fourth (the last) } \\
\text { bulletin in July } 1998 \\
\text { Posttest 2: At the end of } 1998 \text { summer } \\
\text { in the 24th month }\end{array}$ & $\begin{array}{l}\text { Sunscreen and sun } \\
\text { avoidance behaviors: } \\
\text { The use of sunscreen } \\
\text { by parents for their } \\
\text { children, the use of } \\
\text { protective clothing and } \\
\text { canopies and umbrellas } \\
\text { to make shaded areas } \\
\text { Psychosocial } \\
\text { variables: Self-efficacy } \\
\text { of parents to use } \\
\text { sunscreen and their sun } \\
\text { avoidance strategies to } \\
\text { protect their children, } \\
\text { teachers' perceived } \\
\text { norms for sunscreen } \\
\text { use, impediments } \\
\text { to sun avoidance, } \\
\text { sunscreen expectancies, } \\
\text { tanning expectancies }\end{array}$ & $\begin{array}{l}\text { Interventions showed } \\
\text { that parents were } \\
\text { effective in terms of } \\
\text { the sun protection } \\
\text { strategies they used } \\
\text { for their children } \\
\text { in the } 12^{\text {th }} \text { month } \\
\text { and of the use of } \\
\text { sunscreen in the } 24^{\text {th }} \\
\text { month. } \\
\text { In the } 12^{\text {th }} \text { month, } \\
\text { the interventions } \\
\text { had significant } \\
\text { effects on parents' } \\
\text { sun protection } \\
\text { knowledge, teachers' } \\
\text { norms of sunscreen } \\
\text { use, impediments } \\
\text { to sunscreen use, } \\
\text { and sunscreen } \\
\text { expectancies. } \\
\text { In the } 24^{\text {th }} \text { month, } \\
\text { teachers' perceived } \\
\text { norms for sunscreen } \\
\text { use improved } \\
\text { significantly }\end{array}$ & 8 \\
\hline $\begin{array}{l}\text { Gritz et al. }{ }^{33} \\
\text { (2007) } \\
\text { USA }\end{array}$ & $\begin{array}{l}\text { Method: RCT } \\
\text { Theory: Social } \\
\text { cognitive theory } \\
\text { Slogan: Sun } \\
\text { Protection is } \\
\text { Fun! }\end{array}$ & $\begin{array}{l}\text { Age: } 31.3-33.9 \\
\text { years } \\
\text { Sample: Personnel } \\
\text { of } 16 \text { public } \\
\text { kindergartens } \\
\text { and } 4 \text { private } \\
\text { kindergartens } \\
\text { Intervention: } 10 \\
\text { schools } \\
\text { Comparison: } 10 \\
\text { schools } \\
\text { At the beginning } \\
(n=245), \text { in the } 12^{\text {th }} \\
\text { month ( } n=192) \text {, } \\
\text { in the 24th month } \\
(n=225)\end{array}$ & $\begin{array}{l}\text { Two groups, } \\
\text { one comparison } \\
\text { group, and one } \\
\text { intervention } \\
\text { group } \\
\text { For comparison } \\
\text { group: } \\
\text { Continuing } \\
\text { daily standard } \\
\text { applications and } \\
\text { brochure for } \\
\text { prevention of } \\
\text { skin cancer } \\
\text { For intervention } \\
\text { group: Sun } \\
\text { protection } \\
\text { training, video, } \\
\text { bulletin SPF } \\
\text { curriculum, guide } \\
\text { for teachers, and } \\
\text { sunscreen }\end{array}$ & $\begin{array}{l}\text { Measurements: Before the } \\
\text { intervention, in the } 12^{\text {th }} \text { month and in } \\
\text { the } 24^{\text {th }} \text { month } \\
\text { Pretest: At the end of summer of } 1996 \\
\text { Posttest 1: At the end of } 1997 \\
\text { summer in } 12^{\text {th }} \text { month } \\
\text { Posttest 2: At the end of } 1998 \\
\text { summer in the } 24^{\text {th }} \text { month } \\
\text { Application: } \\
\text { Training sessions and video: In spring } \\
\text { of } 1997 \text { and 1998, training for sun } \\
\text { protection and teaching SPF education, } \\
\text { strategies for developing policy and } \\
\text { creating shaded areas, video } \\
\text { Bulletins: In June } 1997, \text { December } \\
\text { 1997, June } 1998 \text { and July } 1998, \text { truths } \\
\text { about the sun, a column by a doctor, } \\
\text { stories for role modeling, interviews } \\
\text { with preschool personnel } \\
\text { Curriculum and guide for teachers: } \\
\text { Introducing/teaching the curriculum to } \\
\text { personnel in summers, giving } 7 \text { lessons } \\
\text { to children in fall and spring months } \\
\text { and basic activities } \\
\text { Sunscreen use: Its use when exposed } \\
\text { to sun, on playground and trips }\end{array}$ & $\begin{array}{l}\text { Behaviors: The use } \\
\text { of sunscreen by staff } \\
\text { for children, protective } \\
\text { dressing and the } \\
\text { use of canopies and } \\
\text { umbrellas to create } \\
\text { shaded areas } \\
\text { Psychosocial } \\
\text { variables: Self- } \\
\text { efficacy of staff to use } \\
\text { sunscreen, teachers' } \\
\text { perceived norms } \\
\text { for sunscreen use, } \\
\text { impediments to sun } \\
\text { avoidance, sunscreen } \\
\text { expectancies, tanning } \\
\text { expectancies, self- } \\
\text { efficacy for sun } \\
\text { avoidance }\end{array}$ & $\begin{array}{l}\text { The 12-month } \\
\text { and 24-month } \\
\text { evaluation of } \\
\text { the interventions } \\
\text { revealed that } \\
\text { interventions had a } \\
\text { significant effect on } \\
\text { behaviors related } \\
\text { to sunscreen use, } \\
\text { wearing protective } \\
\text { clothing, and } \\
\text { staying in the } \\
\text { shade. Knowledge, } \\
\text { self-efficacy, and } \\
\text { norms were among } \\
\text { the psychosocial } \\
\text { variables most } \\
\text { affected by the } \\
\text { interventions }\end{array}$ & 7 \\
\hline
\end{tabular}


lotions. A study by Tripp et al. ${ }^{34}$, (2000) involved a skin cancer prevention program, under the slogan SPF, applied to parents ${ }^{32}$ and teachers ${ }^{33}$ of preschool students. In this program, parents and teachers received sun protection training, based on an SPF curriculum, which included videos and bulletins, five times over a period of one year, and the teachers also were given guides, handbooks, a skin cancer pamphlet, and sunscreen.

\section{Evaluation of programs applied}

The interventions in all the studies reviewed were conducted within the scope of long programs, lasting for one to three years. The results in the studies were measured, just after the intervention, as early as possible, and then at regular intervals of time over the course of 0-3 years. As part of the applied programs, children in kindergarten were observed ${ }^{29,30}$, the knowledge, attitudes, and sun protection practices of kindergarten superintendents were measured ${ }^{30}$, opportunities, impediments, and policies of the school were examined ${ }^{30}$, the sun protection behaviors of children according to parents were identified ${ }^{31}$, and parent modeling of sun protection behaviors for their children and psycho-social variables ${ }^{30,32}$ and teaching modeling of sun protection behaviors for their students and psycho-social variables were investigated ${ }^{33}$

\section{Results obtained}

It was observed that the programs applied in four of the studies were effective in favor of intervention groups $29,30,32,33$, but had no effect in one study ${ }^{31}$. The lessons added to the curriculum were determined to be an effective tool for improving knowledge and comprehension levels of preschool children about sun protection ${ }^{29}$. The interventions made in educational institutions to foster proper sun protection behaviors in children and to educate them on sun protection were observed to result in positive changes in the knowledge/attitudes of school superintendents on sun protection and in using sunscreen products in education institutions ${ }^{30}$. Results of the interventions applied on parents revealed that parents had positive effects on their children in terms of sun protection strategies in the $12^{\text {th }}$ month and of the use of sunscreen in the $24^{\text {th }}$ month ${ }^{32}$. In the program applied for teachers, 12- and 24-month evaluations of the interventions showed that the interventions had a considerable effect on habituating teachers to encouraging the practice of applying sunscreen, putting on protective clothing, and staying in the shade, while the psychosocial variables most affected by the intervention were knowledge, self-efficacy, and norms ${ }^{33}$. In a study conducted by Bauer et al. ${ }^{31}$, (2005) in Germany, training and sunscreen interventions provided for free did not have any effect on the sun protection behaviors of children.

\section{Methodological quality of the studies}

The checklist prepared from the JBI-MAStARI tools for experimental and quasi-experimental studies was used to evaluate the methodological quality of the studies. The quality scores of the studies varied between 7 and 8 . The studies scored 0 points on the following questions from the checklist: "Were participants assigned to intervention/treatment groups by applying the blind method in the studies? (participants do not know the intervention/treatment they received)", "Was the person who placed the participants into study groups unaware of which treatment was received by the participants?" and "Were those who evaluated the results unaware of which group the participants were included?".

\section{Discussion}

The risk for getting skin cancer is higher for people who are light skinned, red haired, have several large moles and freckles, are exposed to sun for a long time, and have a history of sunburn in their childhood 20,21,35,36. The risk for developing melanoma in later periods of life increases 3.5 times for a person with a history of sunburn that causes blisters, even once in childhood, compared to a person who has never had sunburn. This risk is 2 times greater in adults who have had sunburns ${ }^{37}$. In a study by Türkmen et al. ${ }^{38}$ (2010) evaluating skin cancers over a period of ten years, the rate of long-term sunlight exposure was reported to be $90 \%$ for both men and women when etiological factors in patients with skin cancer were examined. Half of melanoma and $78 \%$ of non-melanoma skin cancers can be reduced if appropriate protective precautions are taken at early ages, as evidenced by the strong relationship between sunburns in childhood and skin cancers ${ }^{11}$. It was remarkable that there were only five RCTs on developing sun protection behaviors in preschool children, and that after 2007, there were no trials of this nature conducted. This indicates that there is a strong need for further studies about this issue. It was observed in the studies reviewed that the interventions applied and the models utilized within the scope of the training and follow-up program were effective and usable. Since the efficiency of these programs has not been evaluated for the last 10 years, there is a strong need to plan experimental studies and prospective cohort studies on these programs.

The sample of the school-based studies on sun protection in Turkish society consisted of university students ${ }^{39-46}$, high school students 47,48 , secondary school students ${ }^{49-52}$, primary and secondary school students ${ }^{53}$, and primary school students ${ }^{54}$. High school students were included along with their teachers ${ }^{48}$ in one of these studies, while primary school students were included along with their parents ${ }^{54}$ in another study. There, however, has been no study conducted in preschool students in Turkey. Therefore, studies in Turkey on this age group would be beneficial in raising the awareness of children at an early age about the detrimental effects of the sun, in planning programs focused on developing positive attitudes and behaviors, in creating goals and contents suitable for every age group, and in carrying out studies involving the participation of teachers and parents. It is important that both children and their parents be given training about sun protection methods in nurseries, kindergartens, and primary and secondary education institutions and that these training programs be made into state policy. Furthermore, it is paramount that nurses, who are seen by the World Health Organization as playing a key role in health protection and promotion programs, perform the requisite applications to protect society against skin cancer. The National Education Program for Prevention of Skin Cancer organized by the American Center for Disease Control and Prevention includes plans that involve active engagement of public health nurses in the early diagnosis and prevention of cancer ${ }^{10,55}$. In this role that nurses play, they must teach children and families the importance and purpose of sun protection.

In research studies, researchers must select a suitable conceptual model from a number of different ones available ${ }^{56}$. Piaget ${ }^{57}$ (1965) highlights that peer interaction within a learning setting is important for children insofar as it helps them to evaluate several perspectives as well as their cognitive development and learning. Therefore, the curriculum prepared 
based on Piaget's theory of cognitive development was well received by children, parents, and kindergartens, and it was observed to be effective ${ }^{29}$. The Health Belief Model has been the most frequently used model for forming the conceptual frame of health behavior in the last five decades. This model has been used to explain behavioral changes about health, to maintain health, and to plan intervention studies about protective health behavior ${ }^{58}$. The program based on this model that was prepared for staff and parents for improving sun protection of children who were in nurseries and kindergartens was observed to produce positive changes ${ }^{30}$. Another model used in the studies was the social cognitive theory mode ${ }^{59}$. Social cognitive theory proposes that indirect learning is based on the behaviors of others and observation of these behaviors. According to this type of learning, which is referred to as observational learning, people can acquire general and integrated learning patterns without the need of trial and error ${ }^{60}$. This model was used in two studies conducted with parents ${ }^{32}$ and teachers ${ }^{33}$ to develop sun protection behaviors in preschool students, and the program was observed to be effective in creating the behavioral change. The intervention involving the distribution of informational letters about sun protection and sunscreen use and brochures on preventing melanoma that was applied in one of the studies was determined to be ineffective. In this study, no specific model was used ${ }^{31}$. The high prevalence of using sunscreen products observed in the measurement performed at the beginning of the study was thought to have influenced this result. In systematic reviews, the evaluation for determining the methodological quality of original studies, that is, the strengths and weaknesses of the studies, aims at identifying those studies that are unbiased, with precise evidence to guide researchers in transferring the evidence produced by these studies into practices ${ }^{28}$. The evaluation done for the present systematic review showed that intervention groups were not assigned by using the blind method, individuals assigned to groups knew which interventions were received, and the evaluators knew in which group the participants were involved. Researchers need to state clearly in their reports who was blinded and how they were blinded in the study and how this was supervised, and they must explain who was not blinded and the reasons for this ${ }^{61-63}$. Studies that involve randomization, blinding and follow-up are high cost, in terms of manpower, time, and money, require expert researchers, and are generally conducted on only a limited number of people. It was because of these challenges that the studies reviewed tended not to be population-based and the technique of blinding used in the studies was not stated. In future studies, researchers need to pay close attention to these characteristics, which are required to be taken into account during research, in order to ensure that the evidence produced from the studies is strong.

\section{Conclusion}

In the present review evaluating the interventions performed to develop proper sun protection behaviors of preschool students and the efficiency of these interventions, it was observed that the interventions were applied to students, parents, teachers, and school superintendents. In the programs applied, the behaviors of kindergarten children were observed, the knowledge/attitude of school superintendents was measured, the practices of sun protection and the opportunities, impediments, and policies of the school were examined, the sun protection behaviors of children according to parents were surveyed, the sun protection behaviors modeled by parents and teachers for children were explored, and psychosocial variables were evaluated. The intervention made in four of these five studies included within the scope of the review was determined to be effective. However, the review did discover that there has been a lack of related studies, and therefore, additional RCTs are needed. It is extremely important to raise awareness of sun protection in the early period of childhood, as this is the period kids are especially vulnerable to high levels of sun exposure. This systematic review can serve as a basis for and guide to intervention programs on sun protection for children.

\section{Ethics}

Ethics Committee Approval: Since the article is a systematic review, no ethical approval has been received.

Informed Consent: Since the article is a systematic review, there is no human initiative

Peer-review: External and internal peer-reviewed.

\section{Authorship Contributions}

Concept: A.S., S.Ö., Design: A.S., Data Collection or Processing: A.S., S.Ö., Analysis or Interpretation: A.S., S.Ö., Literature Search: A.S., S.Ö., Writing: A.S.

Conflict of Interest: No conflict of interest was declared by the authors.

Financial Disclosure: The authors declared that this study received no financial support.

\section{References}

1. Jemal A, Siegel R, Ward E, Hao Y, Xu J, Thun MJ: Cancer statistics, 2009. CA Cancer J Clin 2009;59:225-49

2. Aktürk A, Yıldız KD, Bilen N, Bayramgürler D, Kıran R, Onyedi M: Skin cancer cases admitted to Kocaeli University Medical Faculty between years 1996 and 2003. Turkiye Klinikleri J Dermatol 2006;16:44-9.

3. Hunter S, Love-Jackson K, Abdulla R, et al: Sun protection at elementary schools: a cluster randomized trial. J Natl Cancer Inst 2010:102:484-92.

4. Youl PH, Janda M, Aitken JF, Del Mar CB, Whiteman DC, Baade PD: Body site distribution of skin cancer, pre-malignant and common benign pigmented lesions excised in general practice. Br J Dermatol 2011;165:35-43.

5. Li J, Uter W, Pfahlberg A, Gefeller O: A comparison of patterns of sun protection during beach holidays and everyday outdoor activities in a population sample of young German children. Br J Dermatol 2012;166:803-10.

6. Basra MK, Shahrukh M: Burden of skin diseases. Expert Rev Pharmacoecon Outcomes Res 2009:9:271-83.

7. Dobbinson $S$, Wakefield M, Hill $D$, et al: Avustralyalı adölesan ve erişkinlerin hafta sonu güneşten korunma ve güneş yanığı prevalansı ve belirleyicileri, 2 3-2 4 yazı. J Am Acad Dermatol 2009;6:1-13.

8. Lazovich $\mathrm{D}$, Vogel RI, Berwick M, Weinstock MA, Anderson KE, Warshaw EM: Indoor tanning and risk of melanoma: a case-control study in a highly exposed population. Cancer Epidemiol Biomarkers Prev 2010;19:1557-68.

9. Veierød MB, Adami HO, Lund E, Armstrong BK, Weiderpass E: Sun and solarium exposure and melanoma risk: effects of age, pigmentary characteristics, and nevi. Cancer Epidemiol Biomarkers Prev 2010;19:111-20.

10. Uysal A, Özsoy SA, Ergül Ş: Evaluating the skin cancer risks and sunprotection practices of students. Ege Tip Dergisi 2004;43:95-9.

11. Maguire-Eisen M, Rothman K, Demierre MF: The ABCs of sun protection for children. Dermatol Nurs 2005;17:419-22.

12. Glanz K, Mayer JA: Reducing ultraviolet radiation exposure to prevent skin cancer methodology and measurement. Am J Prev Med 2005;29:131-42.

13. Dadlani C, Orlow SJ: Planning for a brighter future: A review of sun protection and barriers to behavioral change in children and adolescents. Dermatol Online J 2008;14:1.

14. Özcan C, Klınç S, Gülmez H: School health and legal status in Turkey. Ankara Med J 2013;13:71-81. 
15. Mert K, Aksayan S: School nursing interventions that promote positive health behavior. Turkiye Klinikleri J Public Health Nurs-Special Topics 2016;2:1-6.

16. Moher $D$, Shamseer $L$, Clarke $M$, et al: Preferred reporting items for systematic review and meta-analysis protocols (PRISMA-P) 2015 statement. Syst Rev 2015;4:1

17. The Joanna Briggs Institute: Joanna Briggs Institute Reviewers' Manual: 2014 edition. Australia, The Joanna Briggs Institute 2014:47-81.

18. Emmons KM, Geller AC, Viswanath $V$, et al: The SunWise policy intervention for school-based sun protection: a pilot study. J Sch Nurs 2008;24:215-21.

19. Grossman D, Leffell DJ: Squamous cell carcinoma. Fitzpatrick's Dermatology in General Medicine. Ed. Freedberg IM, Eisen AZ, Wollf K, Austen KF, Goldsmith LA, Katz SI. New York, McGraw-Hill Education 2008:1028-36.

20. Fehér K, Cercato MC, Prantner I, et al: Skin cancer risk factors among primary school children: investigations in Western Hungary. Prev Med 2010;51:320-4.

21. Heckman CJ, Coups EJ: Correlates of sunscreen use among high school students: a cross-sectional survey. BMC Public Health 2011;11:679.

22. Glenn BA, Lin T, Chang LC, et al: Sun protection practices and sun exposure among children with a parental history of melanoma. Cancer Epidemiol Biomarkers Prev 2015:24:169-77.

23. Klostermann S, Fromme H, Bolte G; Für die GME Studiengruppe: Is there an association between prevention campaign knowledge and sun protection behaviour of parents for their children? results of a parent survey. Gesundheitswesen 2015;77:436-8.

24. Hamilton K, Cleary C, White KM, Hawkes AL: Keeping kids sun safe: exploring parents' beliefs about their young child's sun protective behaviours. Psychooncology 2016;25:158-63.

25. Wan M, Hu R, Li Y, et al: Attitudes, beliefs, and measures taken by parents to protect their children from the sun in Guangzhou City, China. Photochem Photobiol 2016;92:753-9.

26. Day AK, Stapleton JL, Natale-Pereira AM, Goydos JS, Coups EJ: Parent and child characteristics associated with child sunburn and sun protection among U.S. Hispanics. Pediatr Dermatol 2017;34:315-21.

27. Armijo-Olivo S, Stiles CR, Hagen NA, Biondo PD, Cummings GG: Assessment of study quality for systematic reviews: a comparison of the Cochrane Collaboration Risk of Bias Tool and the Effective Public Health Practice Project Quality Assessment Tool: methodological research. J Eval Clin Pract 2012;18:12-8

28. Nahcivan N, Seçginli S: How are the Methodological Quality of Quantitative Studies Included in Systematic Review? Turkiye Klinikleri J Public Health NursSpecial Topics 2017;3(1):10-9.

29. Loescher LJ, Emerson J, Taylor A, Christensen DH, McKinney M: Educating preschoolers about sun safety. Am J Public Health 1995;85:939-43.

30. Crane LA, Schneider LS, Yohn JJ, Morelli JG, Plomer KD: "Block the sun, not the fun": evaluation of a skin cancer prevention program for child care centers. Am J Prev Med 1999;17:31-7.

31. Bauer J, Büttner $P$, Wiecker TS, Luther $H$, Garbe C: Interventional study in 1,232 young German children to prevent the development of melanocytic nevi failed to change sun exposure and sun protective behavior. Int J Cancer 2005; 116:755-61

32. Gritz ER, Tripp MK, James AS, et al: An intervention for parents to promote preschool children's sun protection: effects of Sun Protection is Fun! Prev Med 2005;41:357-66

33. Gritz ER, Tripp MK, James AS, et al: Effects of a preschool staff intervention on children's sun protection: outcomes of sun protection is fun! Health Educ Behav 2007;34:562-77

34. Tripp MK, Herrmann NB, Parcel GS, Chamberlain RM, Gritz ER: Sun protection is fun! A skin cancer prevention program for preschools. J Sch Health 2000;70:395-401

35. Geller AC, Zwirn J, Rutsch L, Gorham SA, Viswanath V, Emmons KM: Multiple levels of influence in the adoption of sun protection policies in elementary schools in Massachusetts. Arch Dermatol 2008;144:491-6.

36. Pour NS, Saeedi M, Semnani KM, Akbari J: Sun protection for children: a review. J Pediatr Rev 2015;3:e155.

37. Cokkinides V, Weinstock M, Glanz K, Albano J, Ward E, Thun M: Trends in sunburns, sun protection practices, and attitudes toward sun exposure protection and tanning among US adolescents, 1998-2004. Pediatrics 2006;118:853-64

38. Türkmen A, Berberoğlu Ö, Bekerecioğlu M, Mutaf M: Skin cancers: retrospective analysis of 10 years. Gaziantep Tıp Derg 2010;16:11-5.

39. Kaymak Y, Tekbaş ÖF, Şimşek I: Knowledge, attitudes and behaviours of university students related to sun protection. Turkderm 2007;41:81-5.
40. Yurtseven E, Ulus T, Vehid S, Köksal S, Bosat M, Akkoyun K: Assessment of knowledge, behaviour and sun protection practices among health services vocational school students. Int J Environ Res Public Health 2012;9:2378-85.

41. Özuğuz P, Kaçar SD, Akyürek FT, et al: Evaluation of first class and end class of medical students' knowledge and behaviors about the sun and the skin. Turk J Dermatol 2014;8:19-22

42. Çınar Fi, Çetin FŞ, Kalender N, Bağcivan G: Determination of sun protection behaviour amoung nursing students. Gülhane Tıp Derg 2015;57:241-6.

43. Yilmaz M, Yavuz B, Subaşi $M$, et al: Skin cancer knowledge and sun protection behavior among nursing students. Jpn J Nurs Sci 2015;12:69-78.

44. Erkin Ö, Ardahan M, Temel AB: Effects of creating awareness through photographs and posters on skin self-examination in nursing students. J Cancer Educ 2018;33:52-8.

45. Haney MO, Bahar Z, Beser A, Arkan G, Cengiz B: Psychometric testing of the Turkish Version of the skin cancer and sun knowledge scale in nursing students. J Cancer Educ 2018;33:21-8.

46. Uğurlu Z, Işık SA, Balanuye B, Budak E, Elbaş NÖ, Kav S: Awareness of skin cancer, prevention, and early detection among Turkish university students. Asia Pac J Oncol Nurs 2016;3:93-7.

47. Sümen A, Öncel S: Effect of skin cancer training provided to maritime high school students on their knowledge and behaviour. Asian Pac J Cancer Prev 2015;16:7769-79.

48. Şenel E, Süslü I: Knowledge, attitudes, and behaviors regarding sun protection, effects of the sun, and skin cancer among Turkish high school students and teachers. Dermatol Sin 2015;33:187-90.

49. Ergul S, Ozeren E: Sun protection behavior and individual risk factors of Turkish primary school students associated with skin cancer: a questionnairebased study. Asian Pac J Cancer Prev 2011;12:765-70.

50. Balyaci $O E$, Koştu N, Temel AB: Training program to raise consciousness among adolescents for protection against skin cancer through performance of skin self examination. Asian Pac J Cancer Prev 2012;13:5011-7.

51. Aygun O, Ergun A: Validity and reliability of sun protection behavior scale among Turkish adolescent population. Asian Nurs Res (Korean Soc Nurs Sci) 2015;9:235-42.

52. Aygün Ö, Ergün A: Investigation of 6-8. grades secondary school students of the sun protection behaviors in Sakarya province. TAF Prev Med Bull 2016;15:312-21.

53. Uslu M, Şavk E, Karaman G, Şendur N: Melanocytic nevi prevalence and the relationship with sun exposure among school children. Turkderm 2009;1:149-54.

54. Kaptanoğlu AF, Dalkan C, Hıncal E: Sun protection in the North Cyprus Turkish Population: knowledge, attitude and behaviors of elementary school children and their families. Turkderm 2012;46:121-9.

55. Centers for Disease Control and Prevention (CDC): Sun-protection behaviors used by adults for their children - United States, 1997. MMWR Morb Mortal Wkly Rep 1998;47:480-2.

56. Fawcett J, Gigliotti E: Using conceptual models of nursing to guide nursing research: the case of the Neuman systems model. Nurs Sci Q 2001;14:33945.

57. Piaget J: The child's conception of number (Original work published in 1941). New York, W. W. Norton and Company 1965:3-33.

58. Ersin F, Bahar Z: Effects of Health Promotion Models on breast cancer early detection behaviors: a literature review. DEUHYO 2012;5:28-38.

59. Bandura A: Social learning theory. Englewood Cliffs. NJ: Prentice-Hall 1977:1-48.

60. Bandura A: Social cognitive theory: an agentic perspective. Annu Rev Psychol 2001;52:1-26.

61. Turlik MA: Evaluating the internal validity of a randomized controlled trial. FAOJ 2009;2:5-9.

62. Karanicolas PJ, Farrokhyar F, Bhandari M: Practical tips for surgical research: blinding: who, what, when, why, how? Can J Surg 2010;53:345-8.

63. Hróbjartsson A, Thomsen AS, Emanuelsson $F$, et al: Observer bias in randomized clinical trials with measurement scale outcomes: a systematic review of trials with both blinded and nonblinded assessors. CMAJ 2013:185:201-11 